\title{
Herpetofauna Roadkills on Langkawi Island, Peninsular Malaysia: The Influence of Landscape and Season on Mortality Distribution
}

(Korban Jalan Raya Herpetofauna di Pulau Langkawi, Semenanjung Malaysia: Pengaruh Landskap dan Musim pada Taburan Kematian)

\section{Norshaqinah Ayob, Muzneena Ahmad Mustapha, Juliana Senawi \& Norhayati Ahmad*}

\section{ABSTRACT}

We examined the spatiotemporal variation of herpetofauna roadkills on roadways in Langkawi Island. A total of 131 roadkills were recorded. The species that exhibited greater mortality was Varanus nebulosus $(n=72)$. There was a significant difference in herpetofauna mortality between dry and wet seasons $(t(11)=-2.330, p=0.04,<0.05)$. The spatial pattern was described by using kernel density estimation. Four collision hotspots were concentrated at the west side of the island, adjacent to vegetation area and forest reserve. Species characteristics, road proximity to the forested area, vegetation cover and traffic volume may influence the high rate of roadkills found. Installation of warning signs, speed restrictions and temporary road closings could reduce traffic accident and significantly reduce mortalities. The study represents a significant improvement over previous research on the island by implementing hotspot analysis. We would suggest analysing habitat suitability and connectivity to increase the ability to predict the location of roadkill hotspots.

Keywords: Hot spot; kernel density; road mortality; spatio-temporal; tropical island

\section{ABSTRAK}

Kami mengkaji variasi reruang dan temporal korban jalan raya haiwan herpetofauna di Pulau Langkawi. Sejumlah 131 korban jalan raya dicatatkan sepanjang pemerhatian dijalankan. Spesies yang menunjukkan kematian yang paling tinggi ialah Varanus nebulosus $(n=72)$. Terdapat perbezaan yang signifikan dalam kematian herpetofauna antara musim kering dan lembap $(t(1)=-2.330, p=0.04,<0.05)$. Corak reruang dikaji dengan menggunakan anggaran ketumpatan kernel. Empat kawasan titik panas korban jalan raya tertumpu di sebelah barat pulaasu, berhampiran dengan kawasan vegetasi dan hutan simpan. Ciri sejarah kehidupan haiwan, jarakjalan ke kawasan hutan, kawasan tumbuhan dan kepadatan lalu lintas mungkin mempengaruhi kadar korban jalan raya yang tinggi yang dijumpai. Pemasangan tanda-tanda amaran, sekatan kelajuan dan penutupan jalan sementara boleh mengurangkan gangguan trafik dan mengurangkan kemalangan trafik melibatkan hidupan liar. Kajian ini menunjukkan peningkatan yang signifikan terhadap penyelidikan terdahulu di Pulau Langkawi dengan pelaksanaan analisis kawasan panas. Kami mencadangkan analisis kesesuaian dan kesambungan habitat dijalankan untuk meningkatkan keberkesanan untuk meramalkan lokasi titik panas korban jalan raya.

Kata kunci: Ketumpatan kernel; korban jalan raya; pulau tropika; reruang dan temporal; titik panas

\section{INTRODUCTION}

Since 2000, the length of road networks worldwide has increased by 12 million $\mathrm{km}$ and it is expected to have an additional of 25 million $\mathrm{km}$ by 2050 (Laurance et al. 2015). In positive contexts, infrastructures provide social and economic benefits through access for rural residents to better health care, education and employment
(Gibson \& Rozelle 2003), as well as facilitating increase in agricultural production (Jacoby 2015). However, as the global road network continues to expand, it may also impose adverse impacts towards the ecosystem, e.g., landscape modification (Saunders et al. 2002), habitat fragmentation (Franklin et al. 2002), pollutions (Ortega 2012; Patricelli et al. 2006) and facilitating access for illegal activities (Borner \& Severre 1986; Clements et al. 2014; Haines et 
al. 2012; Magrath et al. 2007). Besides, the intersection of roads and wildlife is generally agreed to be ecologically hazardous. Road networks may reduce the amount and quality of habitat for the animal community (Debinski \& Holt 2000). Perhaps, the most noticeable effect of roads on a daily basis is wildlife-vehicle collisions (WVC), more commonly referred to as roadkill that affect a wide range of taxa, demonstrating this issue is a major concern (Clevenger et al. 2003). Roadkill often represent a major contributor to terrestrial vertebrate animal population depletion as reported for mammals (Forman et al. 2003), birds (Hodson 1962), reptiles (Baxter-Gilbert et al. 2015) and amphibians (Elzanowski et al. 2009) in many regions worldwide. Wildlife that are highly impacted by roads and highways are those that are with large home ranges (Andrews 1990), slow-moving (MacKinnon et al. 2005), small-sized animals (Barthelmess \& Brooks 2010) and attracted to roads for foraging and basking (da Rosa \& Bager 2012; Glista et al. 2008; Langen et al. 2009; Quintero-Ángel et al. 2012).

Previous literature regarding contributing factors explaining WVC is abundant (Clevenger et al. 2003; Coelho et al. 2008; Farmer \& Brooks 2012). Basically, vulnerability to road mortality in vertebrate terrestrial animals arises from both intrinsic and extrinsic factors. Intrinsic factors that influence vulnerability to road mortality are attributed to life- history traits, behaviour or physiology. Individual diets are seen to affect the likelihood of animals being hit by vehicles, as they are linked to food sources that are sometimes found on the road (Cook \& Blumstein 2013). Additionally, behaviour of animals on the road in response to vehicle likely vary across species, and they could be animals that attempt to cross the roads regardless the traffic intensity or animals that stop in realization of danger. Slow moving animals, such as small mammals (Ascensao et al. 2015), reptiles (MacKinnon et al. 2005), and amphibians (Carr \& Fahrig 2001) are especially susceptible to road mortality. Extrinsic factors that influence vulnerability to road mortality can be both spatial(e.g. surrounding landscapes (Caro et al. 2000; Hernandez 1988), and temporal (e.g. seasonal changes (Seo \& Thorne 2015; Smith \& Dodd 2003). Several other contributing factors influence roadkill including traffic intensity (Farmer \& Brooks 2012; Jones 2000), road type, road surfaces (Garriga et al. 2012; Taylor \& Goldingay 2010), and landscape surrounding the roads (Caro et al. 2000; Hernandez 1988). Because of all these factors, vertebrate roadkill pattern is usually non-random and vary in time and space (Ashley \& Robinson 1996; da Rosa \& Bager 2012; Hartel et al. 2009; Quintero-Ángel et al. 2012).

With the vast development of road networks and increase in WVC over time, it is vitally important to determine areas and periods with high dense of roadkills occurrence to find effective solutions. Roadkill hot moments can be used to predict when road mortality will peak, and facilitate in conservation efforts to focus on this particular times of wildlife accidents. Spatial statistical mappings have recently been used to examine a better understanding of the spatial occurrence of road casualties involving wildlife. A few researchers have specifically focused on developing predictive models of traffic-induced wildlife mortality and implementing GIS-based analysis that are beneficial to be used to identify targeted areas for mitigation measures and finding contributing factors of roadkills occurrence (DeWoody et al. 2010; Gomes et al. 2009; Malo et al. 2004; Prasannakumar et al. 2011; Seiler 2005; Snow et al. 2014).

Despite expanding road networks and global scientific interest in roadkill and road ecology (Seiler 2003), little is known on the spatial and temporal patterns of herpetofauna roadkill in Langkawi UNESCO Global Geopark (LUGGp), even though wildlife road mortality has the potential to significantly affect biodiversity. Currently, the only published data on WVC in LUGGp is from Norshaqinah et al. (2018), who showed how road networks affect vertebrate animals and the contributing factors were discussed. Therefore, the aim of our research was to provide the first results of spatial and temporal patterns of herpetofauna road casualties for LUGGp. We hypothesized that roadkill encounter rate higher during low mean-monthly temperature and wet seasons. Besides, we predicted sections closer to dense- vegetation and settlement area would be associated with higher WVC incidence and less roadkill would occur in a developed area, for instance, the town area. Understanding spatiotemporal of WVC occurrence in Langkawi island is critically important in areas with clearly-seen conflicts between human welfare and nature conservation. Such information would be immensely useful for authorities to identify critical points for implementing cost and time effective mitigation measures for a purpose of making a better integration between ecology and road network at one of the most visited place in the region.

\section{MATERIALS AND METHODS}

\section{STUDY AREA}

Langkawi island is the biggest island in Langkawi Archipelago located at the northern part of west coast Peninsular Malaysia. The topography of the island is low land, mountainous, and hilly terrain, and the Mount Raya is the highest peak, with an altitude of 881 m a.s.1. (Grismer \& Norhayati 2008). The Malaysian climate is strongly dominated by the Southeast Asia maritime continent monsoon, with two monsoon regimes; southwest monsoon and the northwest monsoon (Jabatan Meteorologi Malaysia 2018). The climate of Langkawi Island is characterized by distinct dry seasons between 
November and March and two indistinctive wet seasons, from April to May and August to October (Abdullah et al. 2005), resembling the climate of the northern Peninsular Malaysia. The wet season was defined in the present study as the monthly mean rainfall above $200 \mathrm{~mm}$. The mean annual temperature and precipitation for 2017 were 27.9 ${ }^{\circ} \mathrm{C}$ and $240.35 \mathrm{~mm}$, respectively.

\section{ROADKILL DATA}

Data on herpetofauna roadkills collections were recorded along the selected transects around the island that ran through various functional types, such as forest reserves, mangroves, and town area for 20 days per month from January 2017 to January 2018 (Figure 1) encompassing
$122.7 \mathrm{~km}$ of federal roads. Transects are two and fourlane federal roads with road shoulders that were selected based on adjacent land use, driver's safety and road accessibility. Data collections were performed by an observer in a moving vehicle with a constant speed of $50 \mathrm{kmh}^{-1}$. All dead animals were counted, identified to the species level whenever possible and recorded systematically in a data sheet. Scientific and common names of reptiles and amphibians were identified following on Das (2015) and an online database (Uetz et al. 2018). All carcasses were removed from the road to avoid double counting and few were collected as voucher specimens. Data collection was not conducted at night and bad weather due to limited visibility and safety issue.

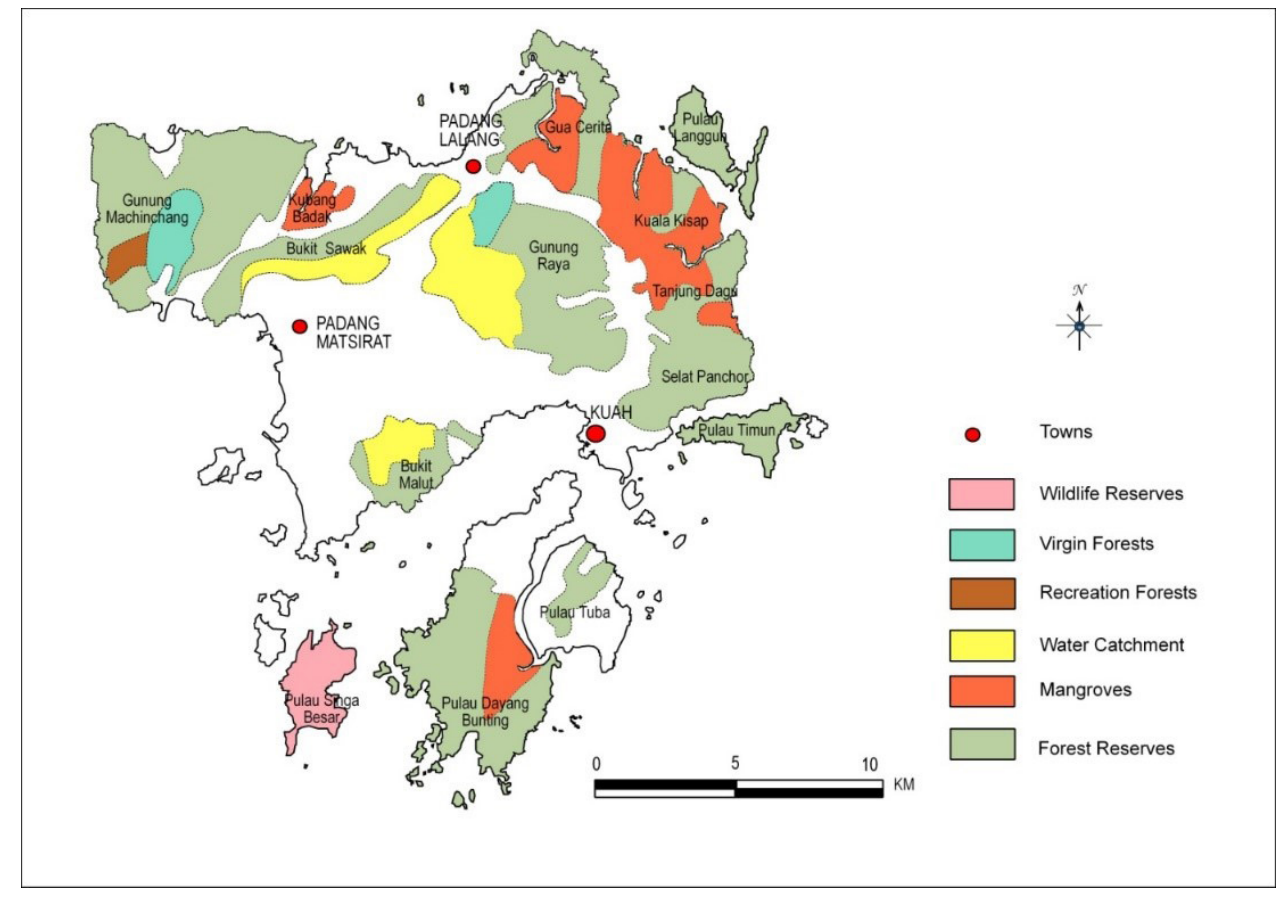

FIGURE 1. Functional forest types on Langkawi Archipelago

\section{GEOREFERENCED DATA COLLECTION}

To assess the spatial pattern of herpetofauna roadkills, we collected geographic coordinates of the carcasses using a hand-held Global Positioning System (GPS) set and plotted the points in the ArcGIS 10.5 software for visual display.

\section{DATA ANALYSIS}

TEMPORAL PATTERN

Andrews et al. (2006) and Glista et al. (2008) have suggested rainfall as a climatic predictor that influenced seasonal variations in both species abundance and activity that will consequently affect WVC patterns. Daily data rainfall was obtained from the Meteorological. Department of Malaysia, and the data were retrieved from the nearest meteorological station. located at Padang Matsirat, Langkawi Island. In the temporal analyses, we used independent $t$-test $(p<0.05)$ to analyse the relationship between the dry and wet seasons with the WVC abundance recorded as the dependent variable. 


\section{SPATIAL PATTERN}

The spatial autocorrelation (Moran's I) was used to analyze the spatial distribution of the WVC spots (Prasannakumar et al. 2011). To identify the accident hot spots, we performed a hot spot analysis by using kernel density estimation (KDE). KDE calculates the dense concentrations of mortalities and identifies clusters within a smoothed surface area (Arevalo et al. 2017). Point density is calculated by adding values of all overlapping kernel surfaces within any cell of determined size. A kernel estimator is calculated according to (1):

$$
f(x)=\frac{1}{n h} \sum_{i=1}^{n} K\left(\frac{x-X}{i} h\right)
$$

where $h$ denotes the bandwidth; $x-X_{i}$ is the distance of each calculating pixel to each roadkill target point $I$; and $K$ represents the kernel function (Silverman 1986). For this analysis, a bandwidth of $500 \mathrm{~m}$ was used as the search radius around each dead individual for both amphibians and reptiles. The output cell size followed input raster dataset and estimated densities were then classified using Jenks method to show the entire range of the density distribution on the map based on minimization and maximization of the variance, respectively, within and between density classes (Jenks \& Caspall 1971). All spatial processing was carried out using ArcGIS software v. 10.5.

\section{RESULTS AND DISCUSSION}

\section{ROADKILL SPECIES AND THEIR CONSERVATION STATUS}

During the study period we had successfully detected a total of 131 carcasses; 127 carcasses (97\%) represented ten reptile species (Table 1). Families included Varanidae $(79.4 \%, \mathrm{n}=104)$, Xenopeltidae $(6.9 \%, \mathrm{n}=9)$, Colubridae $(6.1 \%, \mathrm{n}=8)$, Pythonidae $(2.3 \%, \mathrm{n}=3)$ and Elapidae $(2.3 \%, \mathrm{n}=3)$. The sunbeam snake (Xenopeltis unicolor) was the most recorded roadkill species among snakes $(39.1 \%, n=9)$. The Red-tailed green rat snake was the most common colubrid $(50 \%, n=4)$. Among the reptiles that were killed, the Clouded Monitor Lizard (Varanus nebulosus) constituted the highest (55\%), followed by the water monitor lizard (Varanus salvator) (24\%). Bufonidae represented $3.1 \%(\mathrm{n}=4)$ of roadkills, with the Duttaphrynus melanostictus as the only species recorded. Throughout the sample collection, we found one sample with Near Threatened status which is Reticulated python (Malayopython reticulatus). However, most of the casualties found were globally classified as Least Concern (IUCN 2018).

TABLE 1. List of reptiles and amphibians roadkills found at Langkawi Island, Kedah, Malaysia

\begin{tabular}{lllll}
\hline No. & Taxa & Common name & IUCN & No. of Indivi. \\
\hline & Reptilia & & & 32 \\
1 & Varanus salvator & Water monitor & LC & 72 \\
2 & Varanus nebulosus & Clouded monitor lizard & LC & 9 \\
3 & Xenopeltis unicolor & Sunbeam snake & LC & 4 \\
4 & Gonyosoma oxycephalum & Red-tailed green ratsnake & LC & 1 \\
5 & Ptyas carinata & Keeled rat snake & LC & 2 \\
6 & Coelognathus flavolineatus & Yellow-striped trinket snake & LC & 1 \\
7 & Chrysopelea paradisi & Paradise flying snake & LC & 3 \\
8 & Malayopython reticulatus & Reticulated python & NT & 2 \\
9 & Naja kaouthia & Monocellate cobra & LC & 1 \\
10 & Bungarus candidus & Malayan krait & LC & 4 \\
& Amphibia & & & 131 \\
\hline
\end{tabular}

$\mathrm{NT}=$ Not evaluated $\mathrm{LC}=$ Least concern 


\section{TEMPORAL PATTERNS}

Figure 2 illustrates the temporal pattern of amphibians and reptiles' collisions with vehicles in Langkawi Island from January 2017 to January 2018. Accidents were peaked on April, May, and October 2017. There was a significant difference in WVC abundance between dry and wet seasons $(t(11)=-2.330, p=0.04,<0.05)$ with a higher proportion of herpetofauna were killed during wet seasons $(66 \%, \mathrm{n}=86)$. Of the four amphibians found dead during the study, three of them were observed during wet seasons and one on dry seasons. As predicted, seasonal variations in roadkill numbers occurred. In general, we found a significant difference in the mortality rate between seasons $(t(11)=-2.33, p=0.04,<0.05)$, with a higher number of roadkills during wet seasons ( 86 individuals) on April, May and October (Figure 2). The tripeaked of herpetofauna roadkill in response to seasonal changes could be due to life histories of the various species. Higher number of amphibians roadkills were recorded during rainy seasons due to increase in directed movements such as migrations towards breeding or home site that makes the animal more susceptible to road mortality (Galoyan et al. 2017). Several anuran species, especially those vernal-pool breeding amphibians deposit eggs in temporary pools that form in roadside ditches and blocked drainages during rainy seasons (Dimauro
$\&$ Hunter 2002). The anurans dependent from water and/ or atmospheric humidity for reproduction at least in one phase of their lives, for example, the tadpole phase (Vences \& Köhler 2008). Nevertheless, seasonal factor seems do not intensely influence the breeding activity of Duttaphrynus melanostictus (Asian common toad), the only amphibian species found during the sample collection as tropical anurans exhibit year-round breeding due to favourable climate conditions (Berry 1964). Perhaps, the Asian common toads were susceptible to road mortality as they were attracted to the road during rainy seasons due to food availability. Adult anurans migrate $15 \mathrm{~km}$ at most if important habitat resources such as reproduction sites and nutrition are spatially separated (Sinsch 1990). Temporary pools serve as important habitat for amphibians because of the lack of fish predation and thus allowing the anurans to be the top predators that structure prey communities, feeding on the various species of invertebrates such as mosquitoes and water striders (Dodds 2002). Karunarathna et al. (2013) have proposed that some of the amphibians were observed to feed on insects that came out from the rain-soaked earth. The anuran species were also severely impacted due to size of the animal and limited driver's visibility during rainy seasons that contributed to higher chances of collisions to occur (Elzanowski et al. 2009).



FIGURE 2. Temporal distribution of herpetofauna roadkills in Langkawi island. Roadkill density (black bar) versus monthly mean rainfall (black dashed line) 
Snakes mortality peaked during wet seasons, potentially due to increase in the activity pattern. As ectotherms, snakes' activity is strongly influenced by environmental conditions (Brown \& Shine 2002). Even though snakes mainly reduce their activity during colder temperature, there may be times when some species more active during post-natal dispersal, migration and mate search (Jochimsen 2005). During rainy seasons when the rainwater fills into the ground, the reptiles are forced to come out. Additionally, the reptiles will actively searching for its food such as amphibians and mice that are mostly abundant after the rain (Brown \& Shine 2007). After eating, the snakes like to bask in driveways and this temperature-related behaviours might actually increase susceptibility of reptiles to road accidents. For example, some snake species may be more likely to use edge habitats alongside roads to thermoregulate. When road surface temperature increase and ambient environmental temperature remain cooler especially during wet seasons, some snake species may remain on the road longer than necessary to cross (Kioko et al. 2015).

Based on our study, the varanids represented the majority of the carcasses found during the surveys $(n=71,83 \%)$. However, the varanid susceptibility to road mortality was not affected by the seasonal changes. For instance, the breeding activity of Varanus salvator (Asian water monitor) does not increase during wet season as the varanid breed throughout the year due to abundant food and water resources in tropical areas. Shine et al. (1996) in their studies showed that water monitors in northern Sumatra can breed for most or all of the year. Thus, the varanids are not exposed to road mortality due to increase in migration for breeding purpose. The possible reason was that the lizards are habitat generalist, locally abundant and attracted to the resources or favourable environmental characteristics of road (Forman et al. 2003; Traeholt 1997). Moreover, the monitor lizards are active foragers and often covers a long distance for foraging activity (Gaulke 1991; Træholt 1993). Larger movements and road crossing due to isolated habitats would make the animals more frequently killed on roads (Langton 2002).

\section{SPATIAL PATTERN}

A total of 131 herpetofauna road fatalities were spread across Langkawi Island but several clustered hotspots were identified (Figure 3). Four collision hotspots were found to be concentrated along Pantai Kok and Datai road at the west side of the island, adjacent to Bukit Sawak Forest Reserve. Most roadkill was found on-road sections adjacent to forested, plantation area, with fewer roadkill in sections along town areas. Kernel density estimation

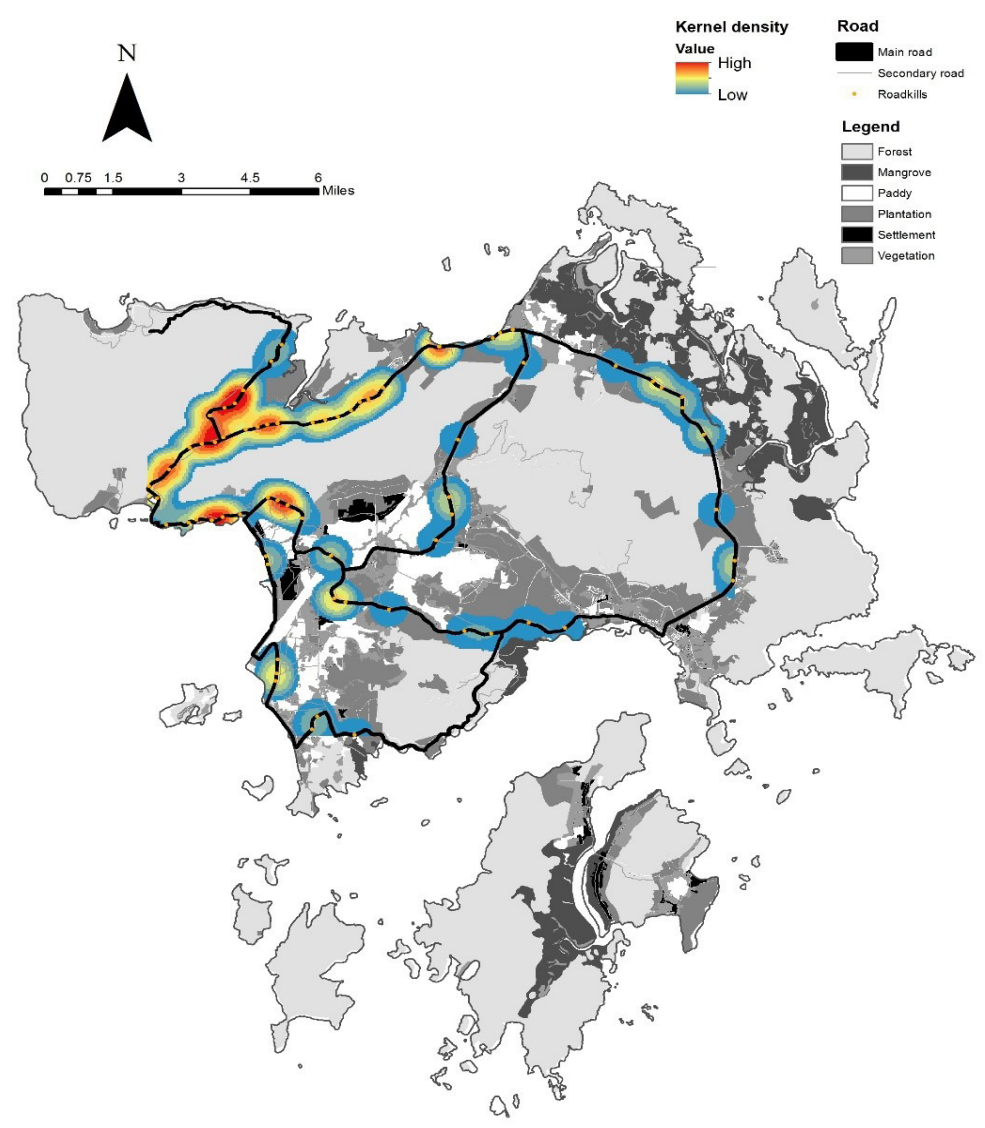

FIGURE 3. Spatial distribution of herpetofaunal roadkills recorded along selected transects in Langkawi island. Kernel density hotspot locations are highlighted using categories ranging from high density to low density clusters (red to blue) 
(KDE) was used to identify the roadkill hotspots. This method can compensate for insufficient data as it produces discrete density surfaces through interpolation (Hashimoto et al. 2016). Generating the probability surface depends on user-defined parameters, such as the bandwidth, method for interpolation, and output format units (Hart $\&$ Zandbergen 2014). Selection of optimal search radius or bandwidth $h$ is essential as it significantly affects the $\mathrm{KDE}$ value. If the value of search bandwidth is too small, it will not produce a continuous smooth surface, and too large bandwidth will result in low-density values and a generalized map (Bailey \& Gatrell 1995; Krisp \& Durot 2007). In general, a large bandwidth will result in a large amount of smoothing and low-density values, producing a map that is generalized in appearance. In contrast, a small bandwidth will result in less smoothing, producing a map that depicts local variations in point densities (Bailey \& Gatrell 1995). Ramp et al. (2005) took the bandwidth as $500 \mathrm{~m}$ and Mountrakis and Gunson (2009) took it as $4000 \mathrm{~m}$. The present study used $500 \mathrm{~m}$ as the bandwidth as it enabled good resolution of clusters (Ramp et al. 2006). Result of spatial analyses for all-roadkilled species showed that the WVC abundance along selected transects was not randomly distributed. Although WVCs occur all over the road, we observed a highly clustering pattern, showing four hotspots as indicated by the kernel density estimation. Most roadkilled hotspots were found on-road sections adjacent to forested and plantation area, with fewer roadkill in sections along town area, located at the southern part of the island which tend to agree with report of Karunarathna et al. (2013) and Vijayakumar et al. (2001). Animals with breeding sites adjacent to roads or the suitable habitat lie across the road or both may have higher risk to get involved in mass road-crossing activity and making them vulnerable to road traffic. This is also in line with other studies and suggests that road sections along dense vegetative cover are potential hotspots for WVC (Clevenger et al. 2003). Besides, the high number of roadkills were also detected at TelukYu area, characterized by dense vegetation, human settlements and tourism spots which make the area experienced massive human activity and high traffic volume. The dead toads (Duttaphrynus melanostictus) were found on the roads near to ditch drainages and grassy plants that could appear to provide suitable habitat and breeding sites for the anurans (Arevalo et al. 2017).

\section{CONCLUSION}

It is necessary to determine particular temporal crash pattern of herpetofauna to predict the critical periods when these animal-vehicle collisions will happen in a specific area. The present study endorsed the role of both extrinsic and probably intrinsic factors in explaining temporal patterns of herpetofauna roadkill occurrence.
Temporal patterns of roadkills varied according to the taxonomic group and seasonal activity. Mass movements of herpetofauna during wet seasons may increase the probability of animal collisions with cars. On the other hand, the spatial pattern was influenced by the landscape and traffic volume factors. Higher mortality occurred along the road near to dense vegetation because of suitable habitats and breeding sites which makes the animals more vulnerable to road accidents. An increase of the tourism occurring in the island may lead to an increase in new road network. Low mortality rates can potentially reduce herpetofauna populations, because local populations may have already been depressed from past cumulative road mortality events. Studies have proven that vehicle collisions are an important source of mortality to many species of reptiles and amphibians that eventually lead to population decline (Elzanowski et al. 2009; Fahrig et al. 1995). It is likely that if the future road expansion is not well planned, it will probably affect wildlife in the long term. The effects of roads can be minimized with the correct placement of mitigation efforts. Installation of warning signs and speed restrictions at hotspots area could reduce traffic disruption and significantly reduce mortalities. Temporary road closing may also help to prevent WVC to occur during wet seasons in the island.

However, there were some limitations, including the carcasses persistence on the road that underestimates the roadkill counts and environmental predictors related to habitat suitability of the reptile and amphibians that was not recorded during the study. Improved sampling design is needed to obtain sufficient data for detailed analysis. Future work is necessary to focus on such as the reclassification of landscape factors according totaxonomic groups. Besides, an extended study on-road risks could be done by analysing habitat suitability and connectivity of the herpetofauna species that would increase the power to predict the location of roadkill hotspots. The information obtained through this research effort may be used to produce further general models of expected mortality hotspots and as guidelines that could be used in framing mitigation strategies to avoid animal-vehicle collision.

\section{ACKNOWLEDGEMENTS}

We are grateful to the Langkawi Research Centre, Institute for Environment and Development (LESTARI), Universiti Kebangsaan Malaysia for permission to stay at the centre. We also thank Prof. Dr. Shukor Md Nor for permission to use laboratory 4116 and ArcGIS software during our study. The publication of this paper is partly funded by Research Grant LIV-2015-03.

\section{REFERENCES}

Abdullah, N., Vikineswary, S., Yusoff, M. \& Desjardin, D.E. 2005. Higher fungi of Northeast Langkawi. Malaysian Journal of Science 24: 95-102. 
Andrews, A. 1990. Fragmentation of habitat by roads and utility corridors: A review. Australian Zoologist 26(3-4): 130-141. doi:10.1016/0006-3207(92)90726-4.

Andrews, K.M., Gibbons, J.W. \& Jochimsen, D.M. 2006 Literature Synthesis of the Effects of Roads and Vehicles on Amphibians and Reptiles. Federal Highway Administration (FHWA), U.S. Department of Transportation, Report No. FHWA-HEP-08-005. Washington, D.C. p. 151.

Arevalo, J.E., Honda, W., Arce-Arias, A. \& Häger, A. 2017. Spatio-temporal variation of roadkills show mass mortality events for amphibians in a highly trafficked road adjacent to a national park, Costa Rica. Revista de Biología Tropical 65(4): 1261. doi:10.15517/rbt.v65i4.27903.

Ascensao, F., LaPoint, S. \& van der Ree, R. 2015. Roads and traffic: Big problems for small mammals. Handbook of Road Ecology. New York: John Wiley \& Sons. pp. 325-333.

Ashley, E.P. \& Robinson, J.T. 1996. Road mortality on the Long Point Causeway. The Canadian Field Naturalist 110(3): 403-412.

Bailey, T.C. \& Gatrell, A.C. 1995. Interactive Spatial Data Analysis. Vol. 413. Essex: Longman Scientific \& Technical.

Barthelmess, E.L. \& Brooks, M.S. 2010. The influence of bodysize and diet on road-kill trends in mammals. Biodiversity and Conservation 19(6): 1611-1629. doi:10.1007/s10531010-9791-3.

Baxter-Gilbert, J.H., Riley, J.L., Lesbarrères, D. \& Litzgus, J.D. 2015. Mitigating reptile road mortality: Fence failures compromise ecopassage effectiveness. PLOS ONE 10(3). doi:10.1371/journal.pone.0120537.

Berry, P.Y. 1964. The breeding patterns of seven species of Singapore Anura. Journal of Animal Ecology 33(2): 227-243. doi: $10.2307 / 2629$.

Borner, M. \& Severre, E.L.M. 1986. Rhino and elephant poaching trends in the Selous Game Reserve. Pachyderm 6(December): 3-4. http://iucn.org/afesg/pachy/pachy06.html. Accessed on 2 December 2018.

Brown, G.P. \& Shine, R. 2002. Influence of weather conditions on activity of tropical snakes. Austral Ecology 27(6): 596-605. doi:10.1046/j.1442-9993.2002.01218.x.

Caro, T.M., Shargel, J.A. \& Stoner, C.J. 2000. Frequency of medium-sized mammal road kills in an agricultural landscape in California. The American Midland Naturalist 144(2): 362-369.

Carr, L.W. \& Fahrig, L. 2001. Effect of road traffic on two amphibian species of differing vagility. Conservation Biology 15(4): 1071-1078. doi:10.1046/j.1523-1739.2001.0150041071.x.

Clements, G.R., Lynam, A.J., Gaveau, D., Yap, W.L., Lhota, S., Goosem, M., Laurance, S. \& Laurance, W.F. 2014. Where and how are roads endangering mammals in Southeast Asia's forests? PLOS ONE 9(12): e115376. doi:10.1371/ journal.pone.0115376.

Clevenger, A.P., Chruszsz, B. \& Gunson, K.E. 2003. Spatial patterns and factors influencing small vetebrate fauna roadkill agregations. Biodiversity Conservation 109(1): 15-26.

Coelho, I.P., Kindel, A. \& Coelho, A.V.P. 2008. Roadkills of vertebrate species on two highways through the Atlantic Forest Biosphere Reserve, southern Brazil. European Journal of Wildlife Research 54(4): 689-699. doi:10.1007/ s10344-008-0197-4.
Cook, T.C. \& Blumstein, D.T. 2013. The omnivore's dilemma: Diet explains variation in vulnerability to vehicle collision mortality. Biological Conservation 167: 310-315. doi:10.1016/j.biocon.2013.08.016.

da Rosa, C.A. \& Bager, A. 2012. Seasonality and habitat types affect roadkill of neotropical birds. Journal of Environmental Management 97(1): 1-5. doi:10.1016/j. jenvman.2011.11.004.

Das, I. 2015. A Field Guide to the Reptiles of South-East Asia. London: Bloomsbury Publishing.

Debinski, D.M. \& Holt, R.D. 2000. A survey and overview of habitat fragmentation experiments. Conservation Biology 14(2): 342-355. doi:10.1046/j.1523-1739.2000.98081.x.

DeWoody, J.A., Nogle, J.M., Hoover, M. \& Dunning, B. 2010. Monitoring and Predicting Traffic Induced Vertebrate Mortality Near Wetlands. Indiana, United States: Purdue University. https://docs.lib.purdue.edu/cgi/viewcontent.cgi ?referer $=\&$ httpsredir $=1 \&$ article $=2604 \&$ context $=$ jtrp

DiMauro, D. \& Hunter Jr., M.L. 2002. Reproduction of amphibians in natural and anthropogenic temporary pools in managed forests. Forest Science 48(2): 397-406.

Dodds, W.K. 2002. Freshwater Ecology: Concepts and Environmental Applications. Kansas: Elsevier.

Elzanowski, A., Ciesiołkiewicz, J., Kaczor, M., Radwańska, J. \& Urban, R. 2009. Amphibian road mortality in Europe: A meta-analysis with new data from Poland. European Journal of Wildlife Research 55(1): 33-43. doi:10.1007/ s10344-008-0211-x.

Fahrig, L., Pedlar, J.H., Pope, S.E., Taylor, P.D. \& Wegner, J.F. 1995. Effect of road traffic on amphibian density. Biological Conservation 73: 177-182.

Farmer, R.G. \& Brooks, R.J. 2012. Integrated risk factors for vertebrate roadkill in southern Ontario. Journal of Wildlife Management 76(6): 1215-1224. doi:10.1002/jwmg.358.

Forman, R.T.T., Sperling, D., Bissonette, J.A., Clevenger, A.P., Cutshall, C.D., Dale, V.H., Fahrig, L., France, R., Goldman, C.R., Heanue, K., Jones, J.A., Swanson, F.J., Turrentine, T. \& Winter, T.C. 2003. Road Ecology; Science and Solutions. Washington: Island Press.

Franklin, A.B., Noon, B.R. \& George, T.L. 2002. What is habitat fragmentation? Studies in Avian Biology 25(25): 20-29.

ht tp://apps.isiknowledge.com/ful1_record. do? product $=$ UA\&search mode $=$ GeneralSearch\&qid $=12 \&$ $\mathrm{SID}=\mathrm{V} 2 \mathrm{fOhdm} 5 \mathrm{o} 53 \mathrm{nb} 6 \mathrm{o} 2 \mathrm{FL} 1 \& \mathrm{page}=2 \& \mathrm{doc}=18 \& \mathrm{colna}$ me $=$ WOS.

Galoyan, E., Vassilieva, A.B. \& Poyarkov, N. 2017. Seasonal activity of terrestrial amphibians in the monsoon lowland forest of southern Vietnam. Herpetological Journal 27(2): 189-199.

Garriga, N., Santos, X., Montori, A., Richter-Boix, A., Franch, M. \& Lorente, G.A. 2012. Are protected areas truly protected ? The impact of road traffic on vertebrate fauna. Biodiversity Conservation 21: 2761-2774. doi:10.1007/s10531-0120332-0.

Gaulke, M. 1991. On the diet of the water monitor, Varanus salvator, in the Philippines. Mertensiella 2: 143-153.

Gibson, J. \& Rozelle, S. 2003. Poverty and Access to Infrastructure in Papua New Guinea. Economic Development and Cultural Change 52(1): 159-185. doi:10.1086/380424. 
Glista, D.J., DeVault, T.L. \& DeWoody, J.A. 2008. Vertebrate road mortality predominantly impacts amphibians. Herpetological Conservation and Biology 3(1): 77-87.

Gomes, L., Grilo, C., Silva, C. \& Mira, A. 2009. Identification methods and deterministic factors of owl roadkill hotspot locations in Mediterranean landscapes. Ecological Research 24(2): 355-370.

Grismer, L.L. \& Norhayati, A. 2008. A new insular species of Cyrtodactylus (Squamata: Gekkonidae) from the Langkawi Archipelago, Kedah, Peninsular Malaysia. Zootaxa 1924: 53-68.

Haines, A.M., Elledge, D., Wilsing, L.K., Grabe, M., Barske, M.D., Burke, N. \& Webb, S.L. 2012. Spatially explicit analysis of poaching activity as a conservation management tool. Wildlife Society Bulletin 36(4): 685-692. doi:10.1002/ wsb. 194

Hart, T. \& Zandbergen, P. 2014. Kernel density estimation and hotspot mapping: Examining the influence of interpolation method, grid cell size, and bandwidth on crime forecasting. Policing 37(2): 305-323. doi:10.1108/PIJPSM-04-2013-0039.

Hartel, T., Moga, C.I., Öllerer, K. \& Puky, M. 2009. Spatial and temporal distribution of amphibian road mortality with a Rana dalmatina and Bufo bufo predominance along the middle section of the târnava mare basin, Romania. NorthWestern Journal of Zoology 5(1): 130-141.

Hashimoto, S., Yoshiki, S., Saeki, R., Mimura, Y., Ando, R. \& Nanba, S. 2016. Development and application of traffic accident density estimation models using kernel density estimation. Journal of Traffic and Transportation Engineering (English Edition) 3(3): 262-270. doi:10.1016/j. jtte.2016.01.005.

Hernandez, M. 1988. Road mortality of the little owl (Athene noctua) in Spain. Journal of Raptor Research 22(3): 81-84.

Hodson, N.L. 1962. Some notes on the causes of bird road casualties. Bird Study 9(3): 168-173. doi:10.1080/00063656209476024.

Jabatan Meteorologi Malaysia. 2018. Fenomena Cuaca. http:// www.met.gov.my/pendidikan/cuaca/fenomenacuaca. Accessed on 10 November 2018.

Jacoby, H.G. 2015. Access to markets and the benefits of rural roads. Royal Economic Society 110(465): 713-737.

Jenks, G.F. \& Caspall, F.C. 1971. Error on chlorophletic maps: Definition, measurement and reduction. Annals of the Association of American Geographers 61(2): 217-244.

Jochimsen, D.M. 2005. Factors influencing the road mortality of snakes on the Upper Snake River Plain, Idaho. In Proceedings of the 2005 International Conference on Ecology and Transportation, edited by Irwin, Garrett, \& McDermott, North Carolina State University: Raleigh, Center for Transportation and the Environment. pp. 351-365.

Jones, M.E. 2000. Road upgrade, road mortality and remedial measures: Impacts on a population of eastern quolls and Tasmanian devils. Wildlife Research 27: 289-296. doi:doi. org/10.1071/WR98069.

Karunarathna, D.M.S.S., Henkanaththegedara, S.M., Amarasinghe, A.A.T. \& de Silva, A. 2013. Impact of vehicular traffic on herpetofaunal mortality in a Savanna Forest, Eastern Sri Lanka. Taprobanica 5(2): 111-119. doi:10.4038/tapro. v5i2.6284.
Kioko, J., Kiffner, C., Jenkins, N. \& Collinson, W.J. 2015. Wildlife roadkill patterns on a major highway in northern Tanzania. African Zoology 50(1): 17-22.

Krisp, J.M. \& Durot, S. 2007. Segmentation of lines based on point densities - An optimisation of wildlife warning sign placement in Southern Finland. Accident Analysis and Prevention 39(1): 38-46. doi:10.1016/j.aap.2006.06.002.

Langen, T.A., Ogden, K.M. \& Schwarting, L.L. 2009. Predicting hot spots of herpetofauna road mortality along highway networks. Journal of Wildlife Management 73(1): 104-114. doi:10.2193/2008-017.

Langton, A.E.S. 2002. Measures to protect amphibians and reptiles from road traffic. In Wildlife and Roads: The Ecological Impact, edited by Sherwood, B., Cutler, D. \& Burton, J.A. London: Imperial College Press. pp. 223-248.

Laurance, W.F., Peletier-Jellema, A., Geenen, B., Koster, H., Verweij, P., Van Dijck, P., Lovejoy, T.E., Schleicher, J. \& Van Kuijk, M. 2015. Reducing the global environmental impacts of rapid infrastructure expansion. Current Biology 25(7): R259-R262. doi:10.1016/j.cub.2015.02.050.

MacKinnon, C.A., Moore, L.A. \& Brooks, R.J. 2005. Why did the reptile cross the road? Landscape factors associated with road mortality of snakes and turtles in the south eastern Georgian Bay area. Parks Research Forum of Ontario. 2005 PRFO Proceedings (December). pp. 153-166.

Magrath, W., Grandalski, R., Stuckey, G., Vikanes, G. \& Wilkinson, G. 2007. Timber Theft Prevention: Introduction to Security for Forest Managers. Washington, D.C.: World Bank Group. http://documents.worldbank.org/ curated/en/258371468246330490/Timber-theft-preventionintroduction-to-security-for-forest-managers.

Malo, J.E., Suarez, F. \& Diez, A. 2004. Can we mitigate animalvehicle accidents using predictive models? Journal of Applied Ecology 41: 701-710.

Mountrakis, G. \& Gunson, K. 2009. Multi-scale spatiotemporal analyses of moose-vehicle collisions: A case study in northern Vermont. International Journal of Geographical Information Science 23(11): 1389-1412. doi:10.1080/13658810802406132.

Norshaqinah, A., Muzneena, A.M., Juliana, S. \& Norhayati, A. 2018. Distribution and abundance of vertebrate animal road-kills in Pulau Langkawi, Kedah, Peninsular Malaysia. Malayan Nature Journal 70(3): 341-348.

Ortega, C.P. 2012. Chapter 2: Effects of noise pollution on birds: A brief review of our knowledge. Ornithological Monographs 74(1): 6-22. doi:10.1525/om.2012.74.1.6.6.

Patricelli, G.L., Blickley, J.L., Auk, S.T., Jul, N. \& Patricelli, G.L. 2006. Avian communication in urban noise: Causes and consequences of vocal adjustment. The American Ornithologist's Union 123(3): 639-649.

Prasannakumar, V., Vijith, H., Charutha, R. \& Geetha, N. 2011. Spatio-temporal clustering of road accidents: GIS based analysis and assessment. Procedia - Social and Behavioral Sciences 21(June): 317-325. doi:10.1016/j. sbspro.2011.07.020.

Quintero-Ángel, A., Osorio-Dominguez, D., Vargas-Salinas, F. \& Saavedra-Rodríguez, C.A. 2012. Roadkill rate of snakes in a disturbed landscape of Central Andes of Colombia. 
Herpetology Notes 5: 99-105. doi:http://dx.doi.org/10.1016/j. jhazmat.2013.02.004.

Ramp, D., Caldwell, J., Edwards, K.A., Warton, D. \& Croft, D.B. 2005. Modelling of wildlife fatality hotspots along the Snowy Mountain Highway in New South Wales, Australia. Biological Conservation 126(4): 474-490. doi:10.1016/j. biocon.2005.07.001.

Ramp, D., Wilson, V.K. \& Croft, D.B. 2006. Assessing the impacts of roads in peri-urban reserves: Road-based fatalities and road usage by wildlife in the Royal National Park, New South Wales, Australia. Biological Conservation 129(3): 348-359. doi:10.1016/j.biocon.2005.11.002.

Saunders, S., Mislivets, M., Chen, J. \& Cleland, D. 2002. Effects of roads on landscape structure within nested ecological units of the Northern Great Lakes Region, USA. Biological Conservation 103(2): 209-225. doi:doi: 10.1016/s00063207(01)00130-6.

Seiler, A. 2003. The Toll of the Automobile: Wildlife and Roads in Sweden. Swedish University of Agricultural Sciences Uppsala.

Seo, C. \& Thorne, J.H. 2015. Disentangling roadkill: The influence of landscape and season on cumulative vertebrate mortality in South Korea. Landscape and Ecological Engineering 11: 87-99. doi:10.1007/s11355-013-0239-2.

Shine, R., Harlow, P.S. \& Keogh, J.S. 1996. Commercial harvesting of giant lizards: The biology of water monitors Varanus salvator in southern Sumatra. Biological Conservation 77(2-3): 125-134.

Silverman, B.W. 1986. Density Estimation for Statistics and Data Analysis. London: Chapman and Hall.

Sinsch, U. 1990. Migration and orientation in anuran amphibians. Ethology Ecology \& Evolution 2(1): 65-79.

Smith, L.L. \& Dodd, C.K. 2003. Wildlife mortality on US highway 441 across Paynes Prairie, Alachua County, Florida. Florida Scientist 66(2): 128-140.

Snow, N.P., Williams, D.M. \& Porter, W.F. 2014. A landscapebased approach for delineating hotspots of wildlife-vehicle collisions. Landscape Ecology 29(5): 817-829.

Taylor, B.D. \& Goldingay, R.L. 2010. Roads and wildlife: Impacts, mitigation and implications for wildlife management in Australia. Wildlife Research 37: 320-331. doi:10.1071/ WR09171.

Traeholt, C. 1997. Activity patterns of free-living water monitor lizards Varanus salvator. Malayan Nature Journal 50: 301315 .

Træholt, C. 1993. Notes of the feeding behaviour of the water monitor, Varanus salvator. Malayan Nature Journal 43: 229-241.

Uetz, P., Freed, P. \& Hošek, J. 2018. The reptile database. http:// www.reptile-database.org. Accessed on 8 September 2018.

Vences, M. \& Köhler, J. 2008. Global diversity of amphibians (Amphibia) in freshwater. Hydrobiologia 595: 569-580.

Vijayakumar, S.P., Vasudevan, K. \& Ishwar, N.M. 2001. Herpetofaunal mortality on roads in the Anamalai Hills, Southern Western Ghats. Hamadryad 26(2): 265-272.

Norshaqinah Ayob, Juliana Senawi \& Norhayati Ahmad* School of Environmental and Natural Resource Sciences Faculty of Science and Technology Universiti Kebangsaan Malaysia 43600 UKM Bangi, Selangor Darul Ehsan Malaysia

Muzneena Ahmad Mustapha Centre for Earth Science \& Environment

Faculty of Science and Technology

Universiti Kebangsaan Malaysia 43600 UKM Bangi, Selangor Darul Ehsan Malaysia

Norhayati Ahmad*

Langkawi Research Centre

Institute for Environment and Development (LESTARI)

Universiti Kebangsaan Malaysia

43600 UKM Bangi, Selangor Darul Ehsan

Malaysia

*Corresponding author; email: amphibia.my@gmail.com

Received: 2 November 2019

Accepted: 15 April 2020 